VA DEPARTMENT OF NATURAL i uvuUiCES AND CONSERVATION

DIVISION OF FORESTRY

INSECT AND DISEASE REPORT

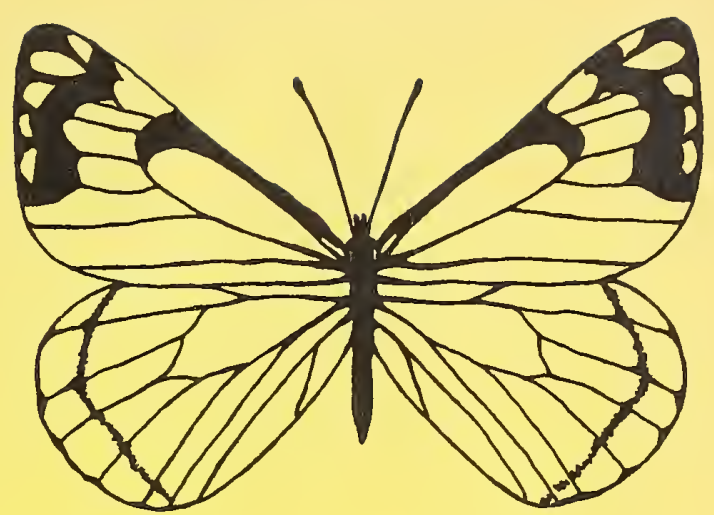

Ground Application of Four

Insecticides on Pine Butterfly

Populations in Montana

1973 FIELD TESTS

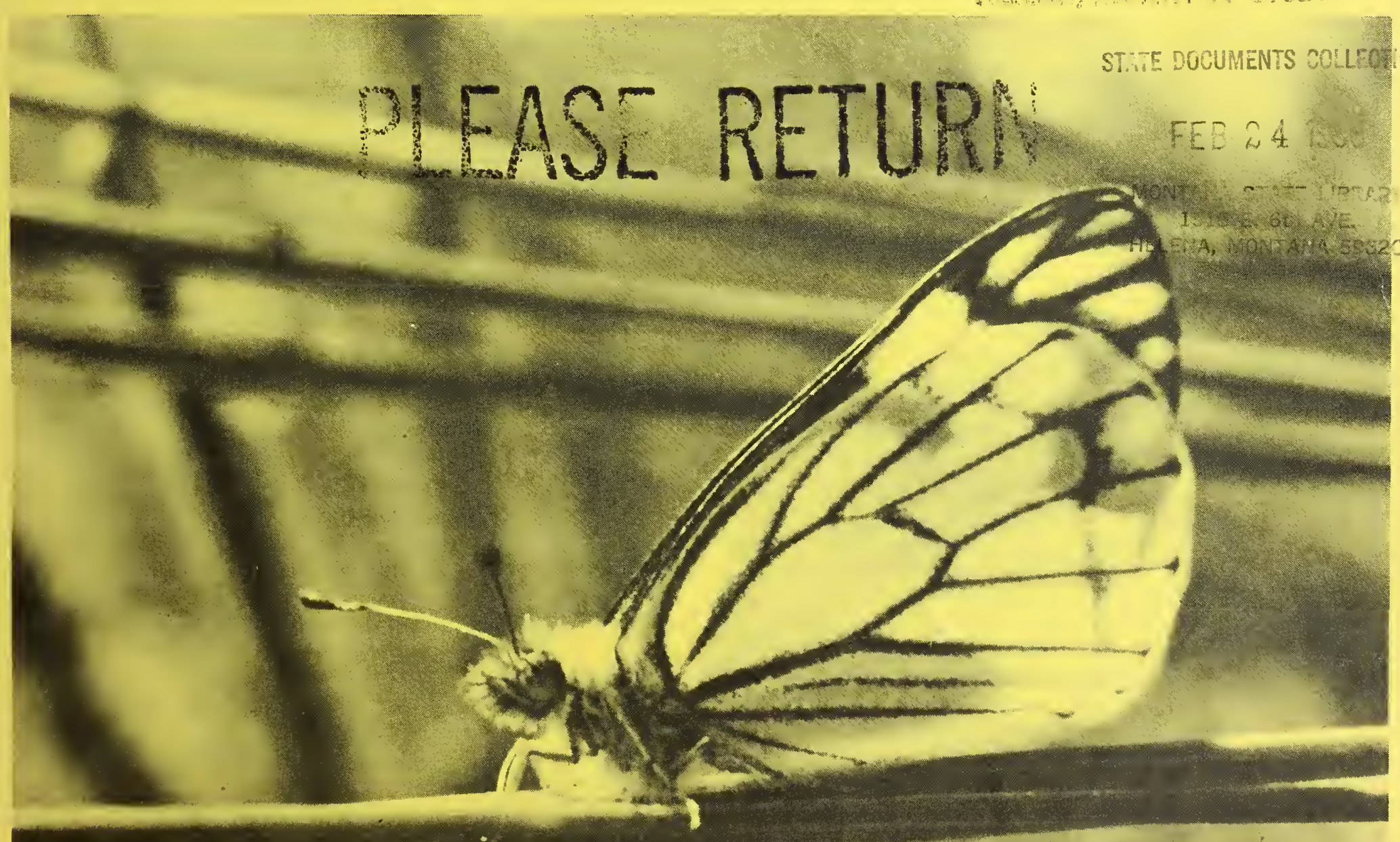


DATE DUE

\begin{tabular}{|l|l|l|l|l|l|}
\hline MAY 1 0 & & & & & \\
\hline & & & & & \\
\hline & & & & & \\
\hline & & & & & \\
\hline & & & & & \\
\hline & & & & & \\
\hline & & & & & \\
\hline & & & & & \\
\hline & & & & & \\
\hline & & & & & \\
\hline
\end{tabular}




\section{GROUND APPLICATION OF FOUR \\ INSECTICIDES ON PINE BUTTERFLY POPULATIONS \\ IN MONTANA-1973 FIELD TESTS}

by

STEVE KOHLER ${ }^{1}$ and JERALD E. DEWEY ${ }^{2}$

\section{ABSTRACT}

Two dosages each of four insecticides, malathion, Zectran, stabilized pyrethrins and Resmethrin, were tested against pine butterfly larvae, Neophasia menapia (Felder \& Felder), on ponderosa pine in the Bitterroot Valley near Fiorence, Montana, in June, 1973. Conventional ground spray equipment was used to treat 24 test clusters of 10 trees each. All treatments were highly successful, with corrected percent control ranging from 98.53 to 100.

\section{INTRODUCTION}

The pine butterfiy, Neophasia menapia (Felder \& Felder), when it reaches epidemic levels, is a serious defoliator of ponderosa pine, Pinus ponderosa (Laws). Considerable mortality of trees denuded of needles by feeding of the larvae can occur (Evenden, 1940 and Cole, 1971). Since 1893 there have been five documented pine butterfly outbreaks. The last of these was detected in the Bitterroot Valley of Montana in 1969 (Bousfield and Ciesla, 1971). By 1972, ponderosa pine on approximately 40,000 acres of State, private and National Forest lands in the Bitterroot Valley and near Missoula showed aerially visible defoliation (Dewey et.al., 1973). In addition to damage in the forest situation, a number of ponderosa pine serving as yard and shade trees suffered noticeable defoliation. Concern was expressed by many landowners who feared the loss of valuable trees from defoliation by pine butterfly larvae (Bousfield and Dewey, 1972).

Only one pine butterfly outbreak has been chemically treated. An estimated 255,400 acres of ponderosa pine on the Boise National Forest, Idaho, were aerially sprayed with DDT in 1964 (Cole, 1966). UTtimately less than one percent of the pine stand died. Since withdrawal of the EPA registration of DDT in 1971, home owners and land managers have been without a chemical tool for pine butterfiy control.

1

Entomologist, Department of Natural Resources and Conservation, Division of Forestry, State of Montana, Missoula, Montana.

2

Entomologist, USDA Forest Service, Region 1, Division of State and Private Forestry, Missoula, Montana. 
DATE DUE

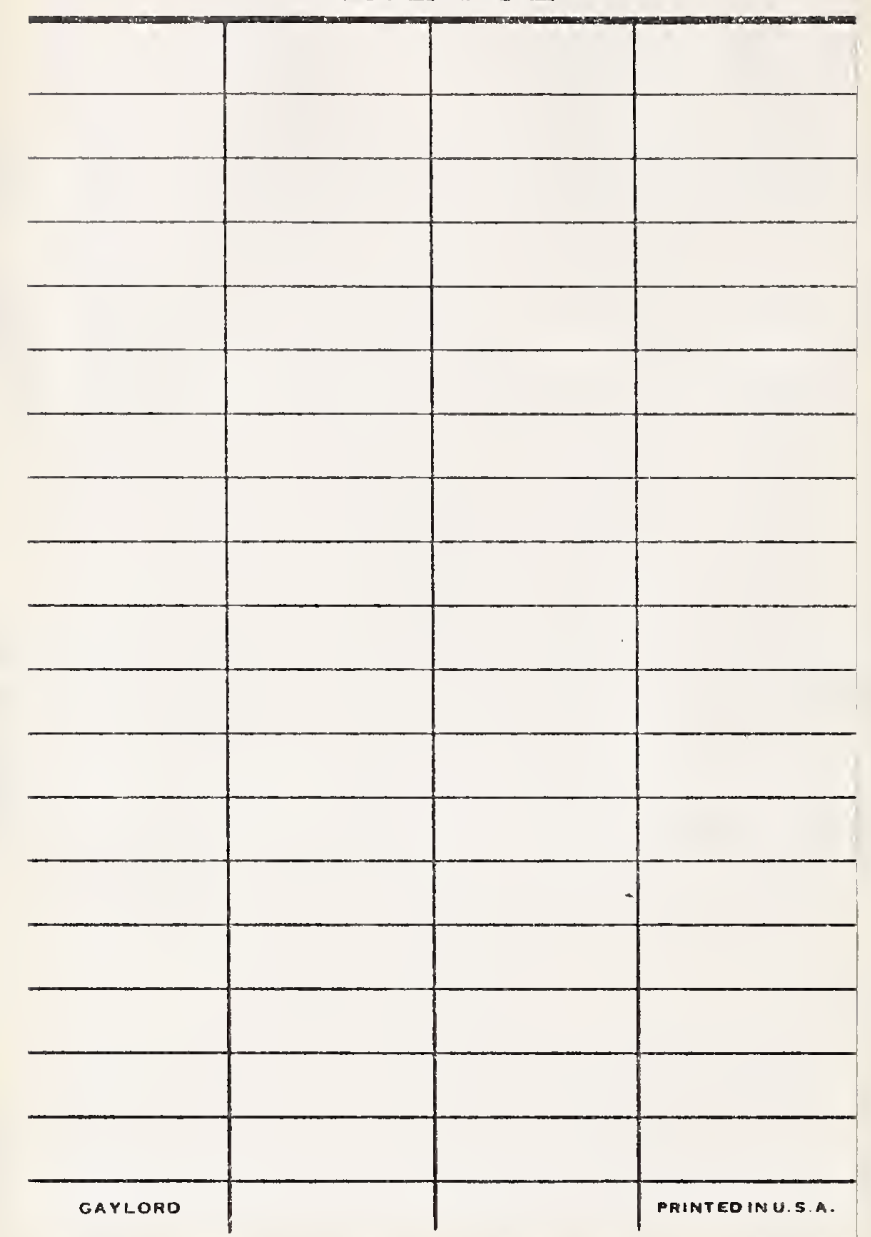


This field test was designed to lead to the registration of one or more nonpersistent materials for pine butterfly control using ground application techniques. These chemicals would then be available to private home owners and forest managers to protect valuable trees in yards, recreation areas, etc., should the need arise in future years. Additional tests were conducted in 1973 by the U.S. Forest Service to find suitable materials for aerial application.

\section{MATERIALS AND FORMULATION}

A series of 14 short-lived insecticides has been laboratory screened and their effect on pine butterfiy Tarvae compared to the effect of DDT (Lyon and Brown, 1971). Al1 but one of the materials tested showed a greater contact toxicity to the pine butterfly than DDT. As a result of this insecticide screening and more recent laboratory testing, the following materials were selected for field testing:

1. Malathion

2. Zectran

3. Stabilized pyrethrins

4. Resmethrin

Reasons for the selection of each material follow:

1. Malathion - Malathion was 1.6 times as toxic as DDT to pine butterfiy Tarvae treated in the laboratory. It also has a low mammalian toxicity. It is registered for use against many pests of vegetables, fruits, ornamentals and forests. It is relatively inexpensive and easy for the landowner interested in treating individual trees to obtain.

2. Zectran - Zectran was 2.4 times as toxic to pine butterfly larvae in the Taboratory as DDT. It is current7y registered and available for forest spraying against some other forest defoliators. Much is known on its behavior in the environment and on non-target organisms. It has a very low mammalian dermal toxicity.

3. Stabilized pyrethrins - This material was selected because of its high toxicity to pine butterfly larvae (62 times greater contact toxicity than DDT) and its low toxicity to vertebrates. Considerable data has been collected on its effect on other organisms.

4. Resmethrin - In recent laboratory tests this material resulted in high mortality levels when applied at low concentrations to larvae similar to the pine butterfly. It has very low persistence, being stable in sunlight for no more than a few hours.

Specific formulations used in the tests were: (1) Zectran - Zectran $2 E$ Emulsifiable Concentrate, provided by Dow Chemical Co.; (2) MaTathion - Cythion $8 \mathrm{E}$ premium grade malathion, emulsifiable liquid, purchased from Stauffer Chemical Co.; (3) Pyrethrins - MGK Pyrocide stabilized growers spray 7083 in a stabilized $1.4 \%$ emulsifiable concentrate, provided by McLaugh7 in Gormley King Co.; and (4) Resmethrin - SBP-1382-2 EmuTsifiable Concentrate Xy, provided by S.B. Penick and $\mathrm{Co}$. 

Each of the materials was diluted with water to obtain dosages of .01 ib. per 10 gallons and .02 1b. per 10 gallons for both stabilized pyrethrins and Resmethrin; .05 lb. per 10 gallons and $.075 \mathrm{lb}$. per 10 gallons for Zectran, and 21 lb. per 10 gallons and .83 lb. per 10 gallons for malathion.

Since cost of material is an important factor in consideration of individual tree treatment by landowners, costs of treatment with the four materials tested were computed and are compared to Table 1.

Table 1. A list of insecticides and dosages selected for the ground application test and their respective costs.

\begin{tabular}{|c|c|c|c|c|}
\hline Material & $\begin{array}{l}\text { Cost/ib. } \\
\text { Technicai }\end{array}$ & Dosage & $\begin{array}{l}\text { Cost of } \\
\text { insecticide } \\
\text { per gal. of } \\
\text { final mix }\end{array}$ & $\begin{array}{l}\text { Cost of } \\
\text { insecticide } \\
\text { at } 10 \text { gal. } \\
\text { spray per } \\
\text { tree }\end{array}$ \\
\hline $\begin{array}{l}\text { Stabilized } \\
\text { Pyrethrins } \\
\text { (Formula 7083) }\end{array}$ & $\$ 50.00$ & $\begin{array}{l}.01 \mathrm{lb} / 10 \mathrm{gal} \\
.02 \mathrm{lb} / 10 \mathrm{gal}\end{array}$ & $\begin{array}{l}.050 \\
.10\end{array}$ & $\begin{array}{r}.50 \\
1.00\end{array}$ \\
\hline $\begin{array}{l}\text { Resmethrin } \\
(24.3 \% \text { SBP-1382- } \\
\text { 2EC) }\end{array}$ & 48.00 & $\begin{array}{l}.01 \mathrm{lb} / 10 \mathrm{gal} \\
.02 \mathrm{lb} / 10 \mathrm{gal}\end{array}$ & $\begin{array}{l}.048 \\
.096\end{array}$ & $\begin{array}{l}.48 \\
.96\end{array}$ \\
\hline Zectran 2E & 7.50 & $\begin{array}{c}1 \mathrm{qt} / 100 \mathrm{gal} \\
(.05 \mathrm{lb} / 10 \mathrm{gal}) \\
1 \frac{1}{2} \mathrm{qt} / 100 \mathrm{gal} \\
(.075 \mathrm{lb} / 10 \mathrm{gal})\end{array}$ & $\begin{array}{l}.037 \\
.056\end{array}$ & $\begin{array}{l}.37 \\
.56\end{array}$ \\
\hline Malathion & 1.00 & $\begin{array}{l}\frac{1}{4} \% \\
1 \%\end{array} \quad(.21 \mathrm{lb} / 10 \mathrm{gal})$ & $\begin{array}{l}.021 \\
.083\end{array}$ & $\begin{array}{l}.21 \\
.83\end{array}$ \\
\hline
\end{tabular}

\section{TEST DESIGN}

1. The ground spray tests were conducted on State and private lands in the Sweeney Creek drainage near Florence, Montana, and on private lands at Antrim Point on the east side of the Bitterroot River (Figure 1).

2. In total, 27 clusters of 10 trees each were selected at intervals alona existing roads and old skid trails in the test areas (Figure 2). This was done so the clusters could be reached by the spray vehicle.

3. There were nine treatments (2 dosages of malathion, 2 dosages of Zectran, 2 dosages of stabilized pyrethrins, 2 dosages of Resmethrin and control) with three replications per treatment (one 10-tree cluster per replicate). 
Digitized by the Internet Archive in 2016

https://archive.org/details/groundapplicatio1973kohl 


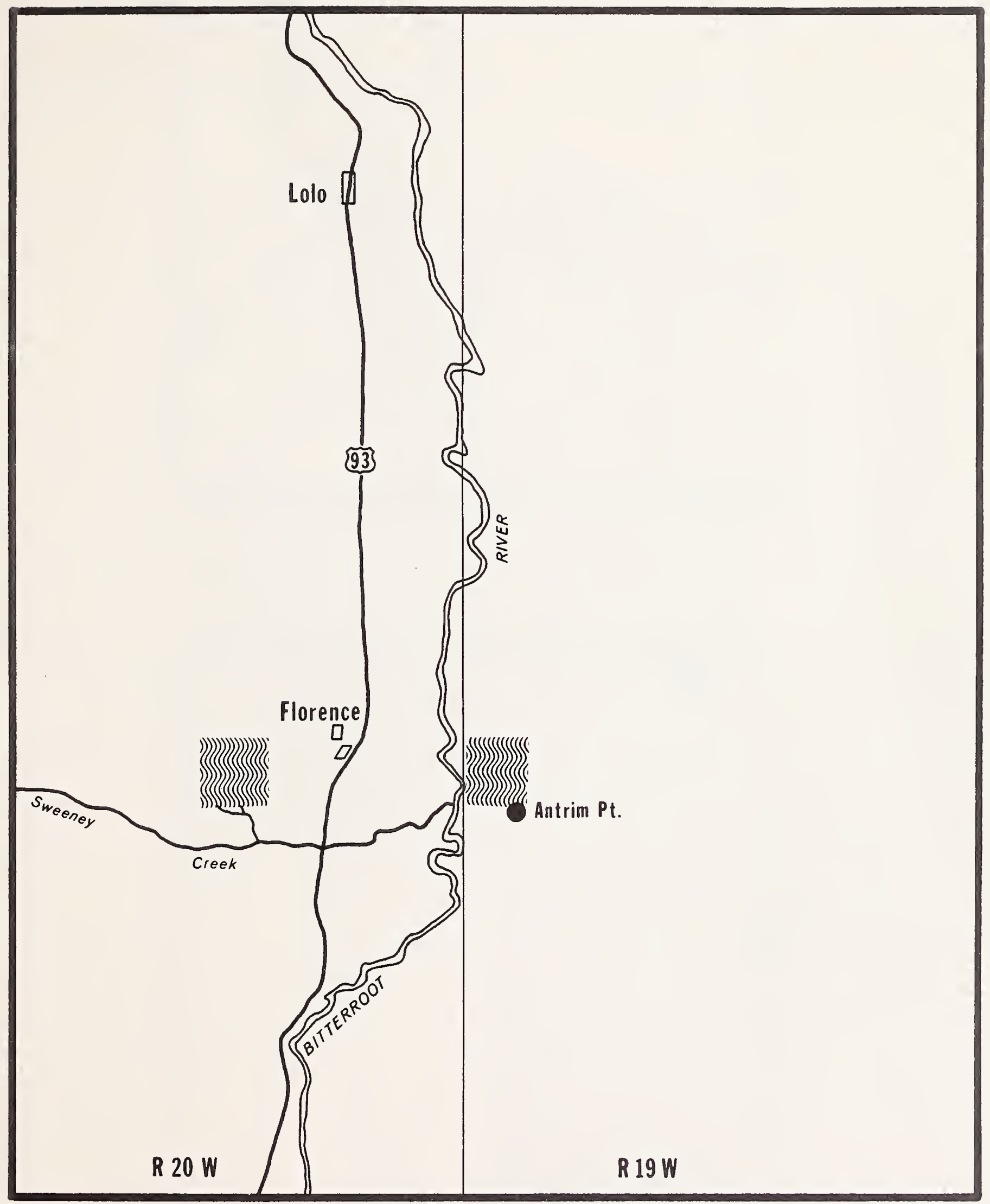

Figure 1. Location of 1973 ground spray test areas in the Bitterroot Valley, Montana 



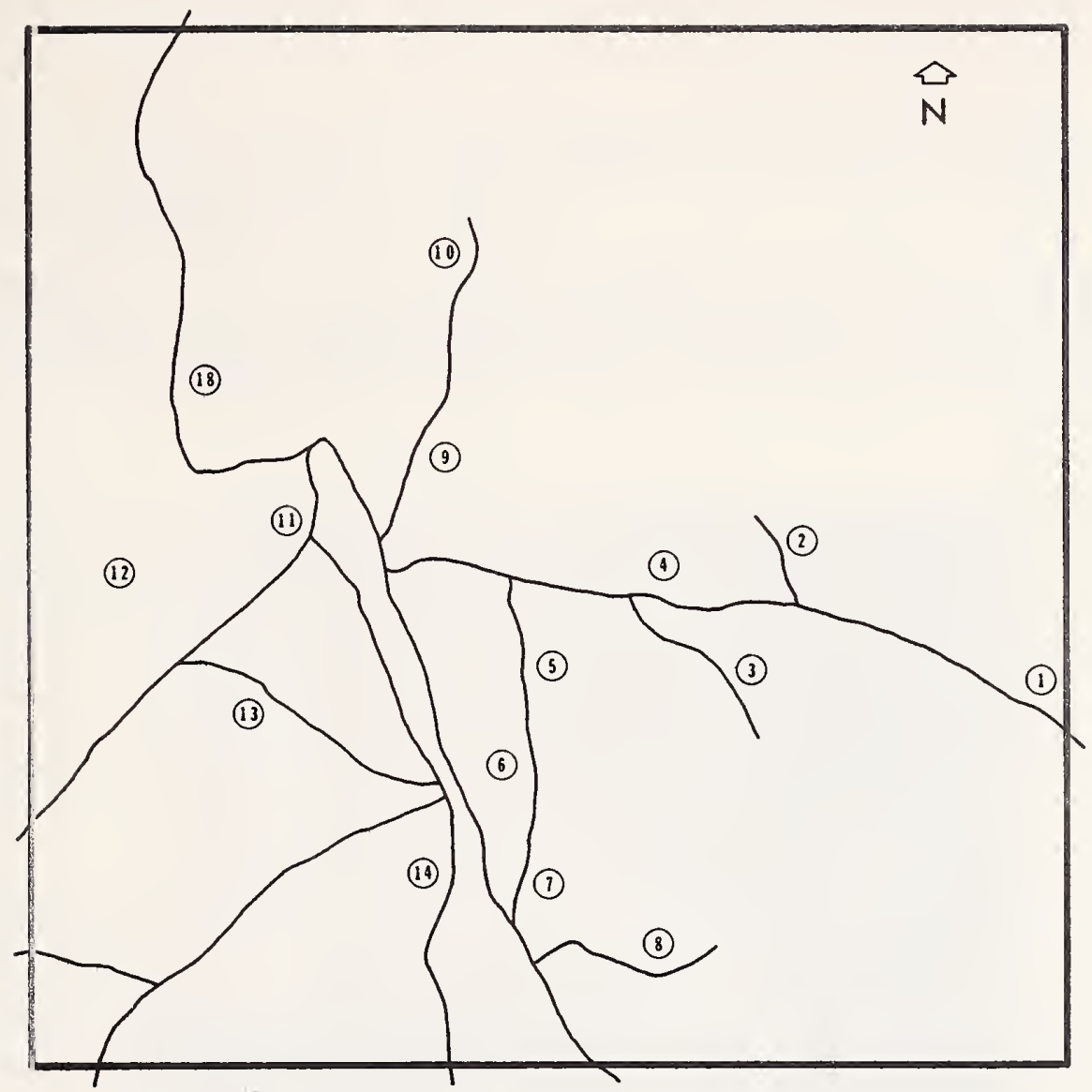

(16)

(15) (11)

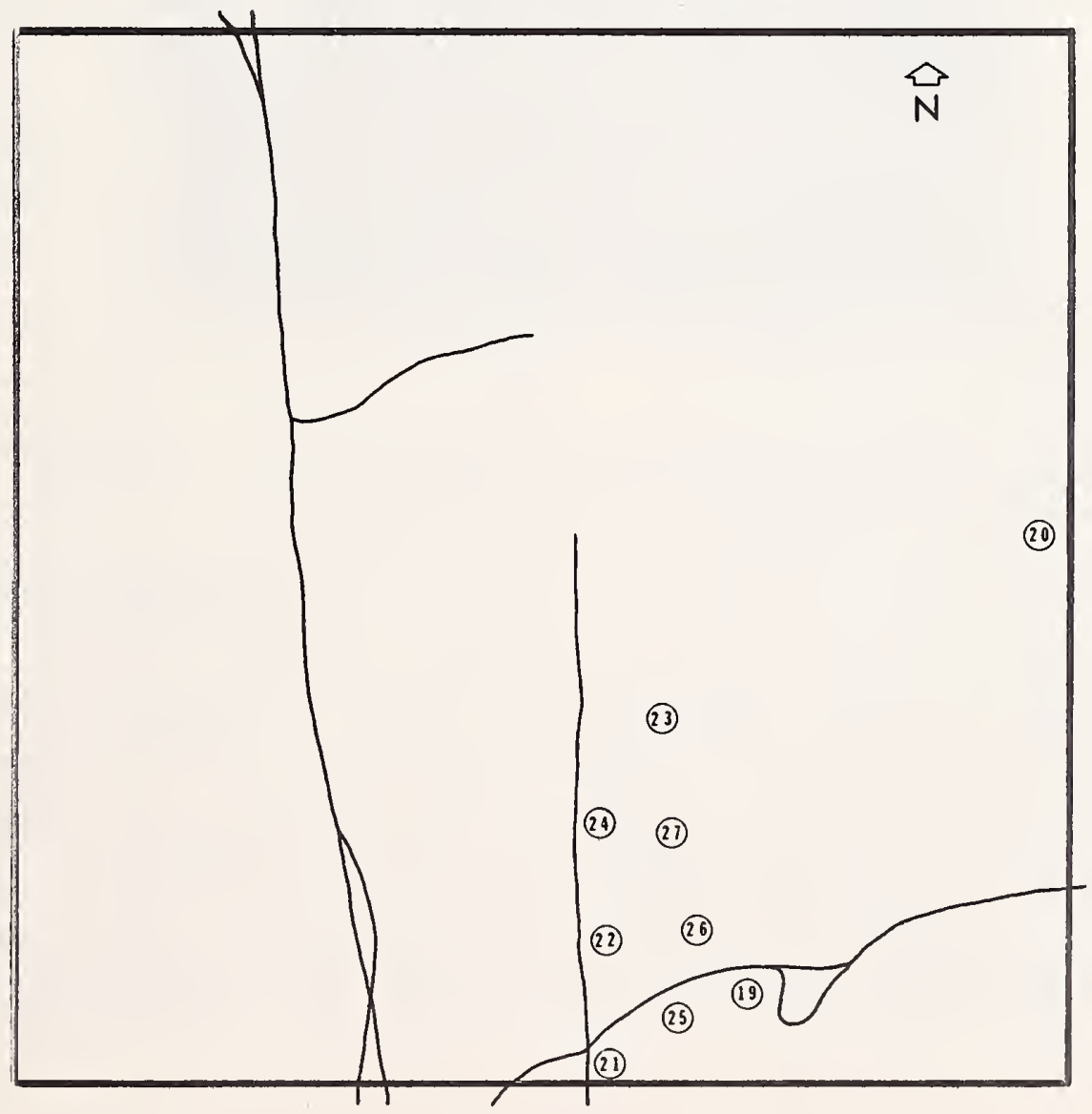

Figure 2. Location of test tree clusters in the 1973 ground spray test in Sweeney Creek (top) and at Antrim Point (bottom). 

A distance of not less than approximately 100 yards was allowed between clusters to minimize spray drift.

4. Pine butterfly larvae populations on each tree were sampled by cutting six foliated branch tips (approximately 15 inches in length) from mid-crown of each tree with an extendable pole pruner with catch basket attached (Figure 3).

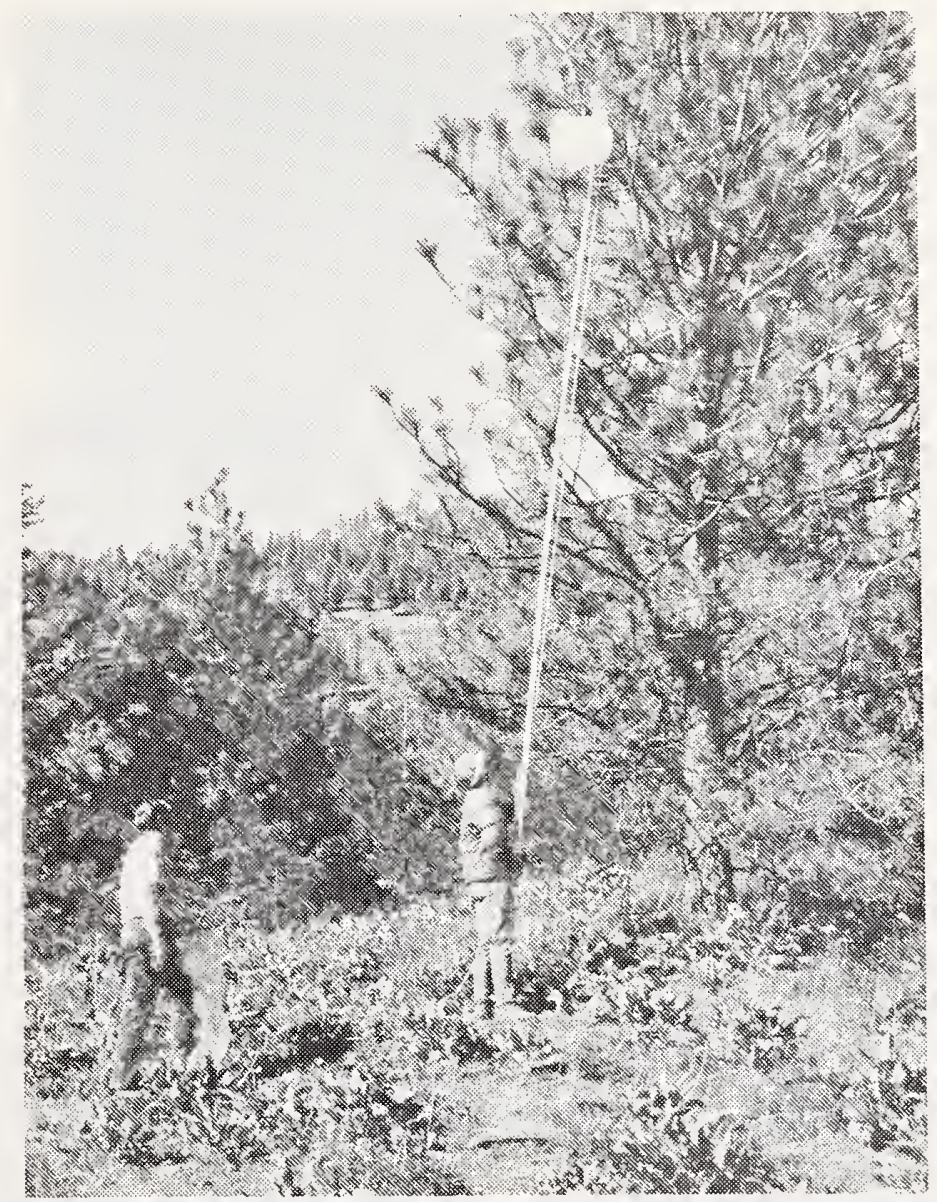

Figure 3. Collecting pine butterfly larvae samples.

All trees in each cluster were sampled immediately before spraying and again 4 days after spraying.

5. Individual sample trees in each cluster were 20 to 50 feet tal1. Each tree selected was checked to make sure sufficient foliage remained to harbor high enough larvae populations to make the test statistically sound (not less than 6 larvae per sample branch). Trees taller than 50 feet were not selected because of limitations in the pole pruner used to clip sample branches and in the height to which spray could be directed efficiently from ground level. Trees were marked with a yellow paper tag giving the tree and cluster number and with streamers of red flagging to assist in relocating. 

The design, then, consisted of 27 clusters of 10 trees each for a total of 270 trees. The choice of treatment for a particular cluster of 10 trees was random. A total of 1,620 branches was cut during each of the two sample periods. The basic sample unit was six approximately 15-inch branches taken from mid-crown. Pine butterfly larval population densities were expressed as the number of larvae per linear inch of foliated branch.

\section{SPRAY APPLICATION}

Spray applications were begun after development samples indicated egg hatch was completed. Larvae were in 1 st and 2 nd instar stages when sprayed. The four insecticides were randomiy placed on the spray schedule. Resmethrin was sprayed on June 5, malathion on June 6, Zectran on June 9, and stabilized pyrethrins on June 10. All sprays, were applied to the point of run-off using a Montana Division of Forestry fire pumper (Figures 4: and 5).
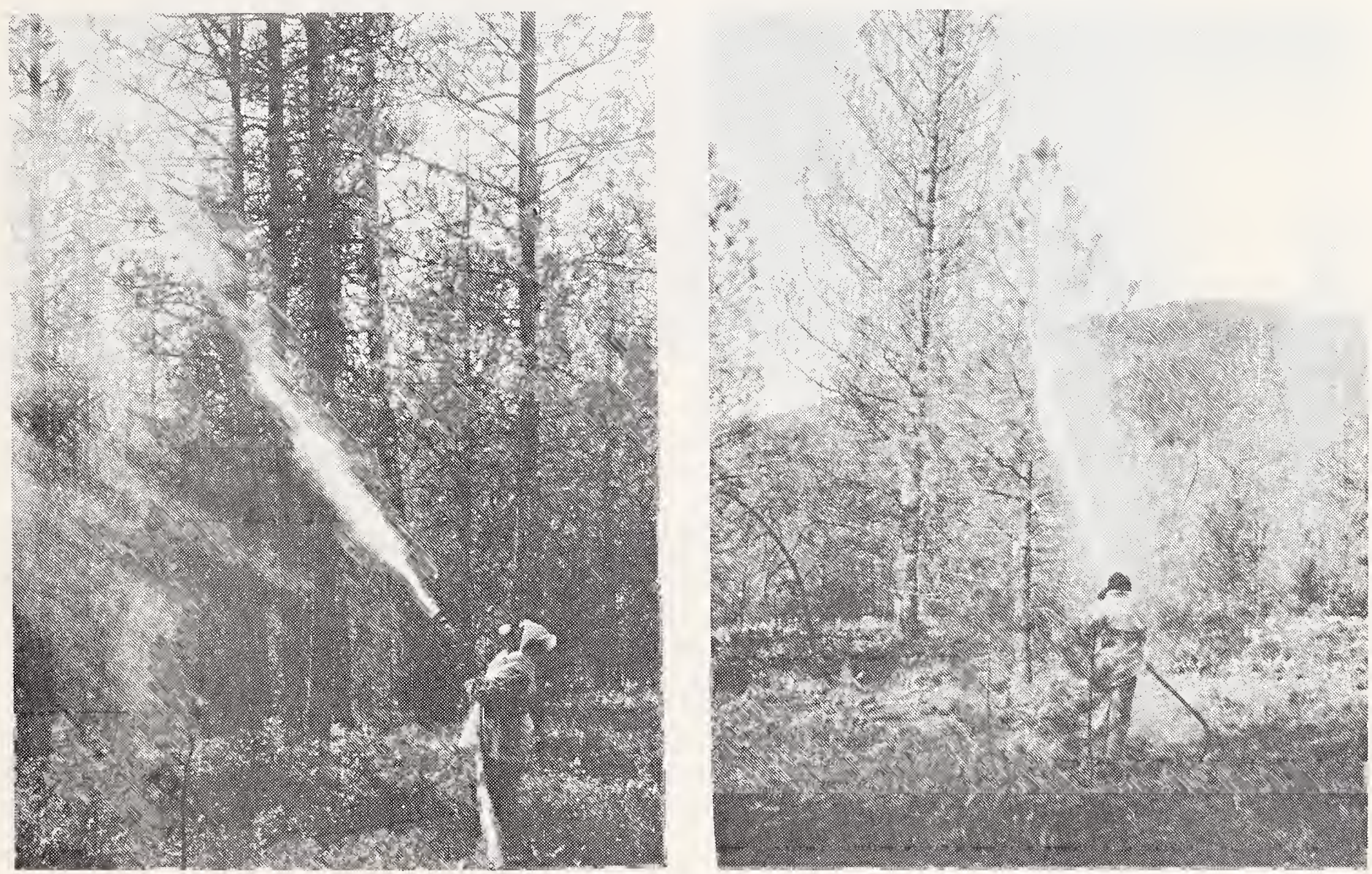

Figures 4 and 5. Application of ground sprays.

The fire pumper was equipped with a centrifugal four-stage WGC-4-SP Pacific pump connected to 200 feet of one-inch hard rubber hose. The nozzel used was an E1khart Select-0-Flow, adjustable from 10 to 30 gallons flow per minute. The pump, 

hose reel and a 500 gallon fiberglass tank were mounted on a 20,000 GVW Ford truck (Figure 6).

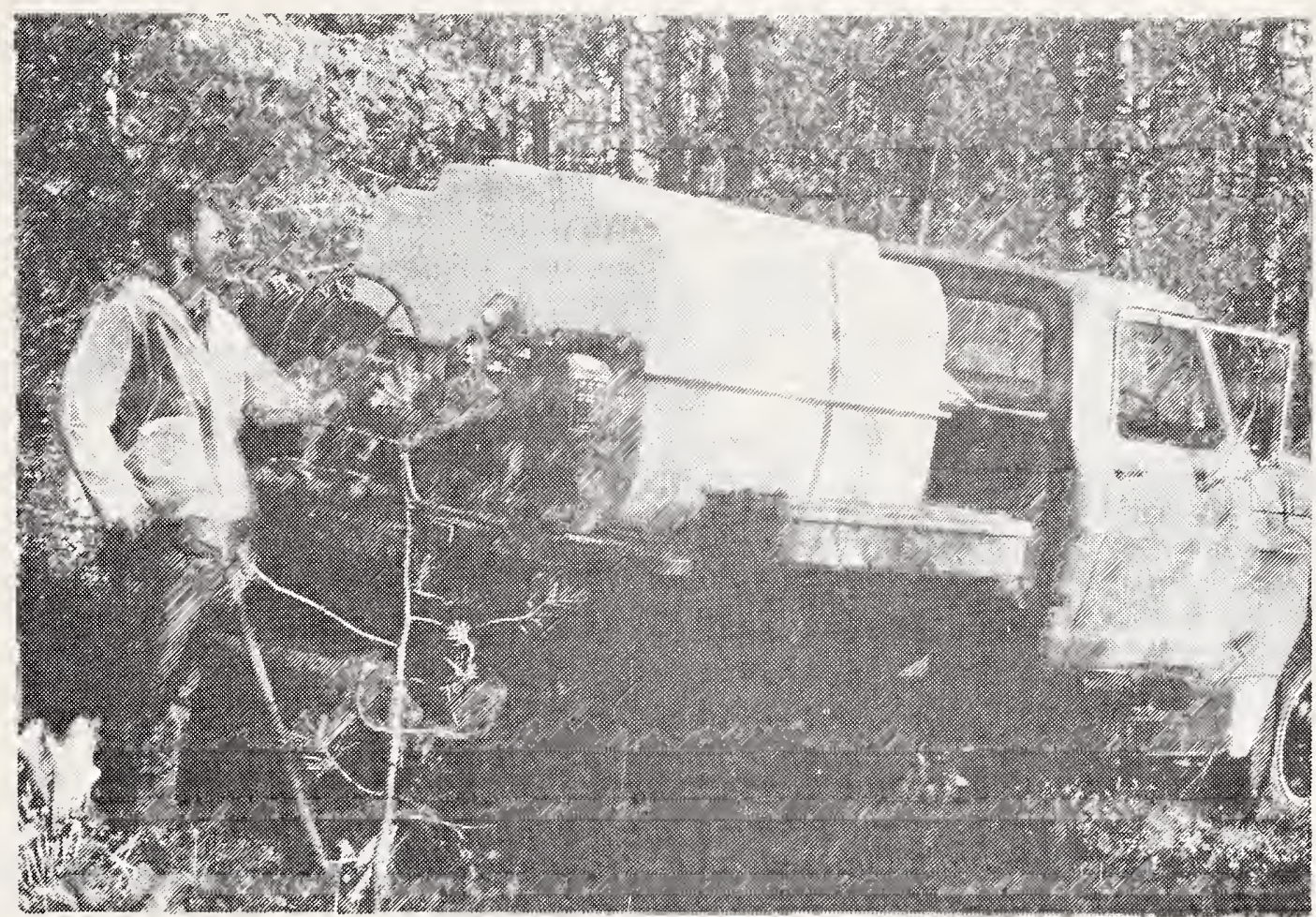

Figure 6. Equipment used in ground spray application.

Only one insecticide was applied on each spray day. Enough of each dosage was mixed in the tank to complete spraying of the three 10-tree clusters. The low dosage of each insecticide was applied first; then the tank was emptied and flushed before being filled with the high dosage. After diluting, the sprays were allowed to recirculate in the tank for approximately 10 minutes to insure complete mixing. At completion of spraying each day, the tank, hose and pump were flushed with Nutra-sol. The average amount of spray required to treat each tree was between five and ten gallons. A few larger, open-arown trees required more. Spray applicators wore protective clothing and a respirator when applying the material.

\section{SPRAY ASSESSMENT}

Pre-spray larval populations on trees in each cluster were sampled immediately before the spray was applied to the cluster. Post-spray populations were sampled 4 days after spraying. The check clusters were sampled June 7 and again June 11. Sampling was accomplished by cutting six branches, each approximately 15 inches long, from mid-crown of each sample tree with an extendable pole pruner. Branches fell into a cloth basket attached near the pruner head (Figure 3) and were lowered to the ground. Branches falling out of the basket were discarded and others cut in their place. The six sample branches from each tree 

were placed in a plastic bag with a card indicating tree and cluster numbers and date. A separate bag was used for each tree. The plastic bags were placed in large canvas sacks which held 15-20 bags and were kept in a cool, shady location until sampling was completed. The canvas sacks containing the plastic bags with sample branches were then transported in a pickup truck to the laboratory in Stevensville.

Under supervision of an entomologist, insect counters in the laboratory removed foliage from the bags and placed all insects in petri-dishes. Pine butterfly larvae were counted and inches of foliage on the branches measured. Effectiveness of each insecticide and dosage was evaluated by comparing pre-spray and post-spray larval population counts on the sample branches. Results were expressed in terms of survival ratio and corrected percent control.

\section{RESULTS}

Results of the ground test spraying of the four insecticides against pine butterfly larvae are summarized in Table 2. Pre-spray and post-spray densities are expressed in the table as number of larvae per linear inch of foliated branch. The corrected percent control figures were computed by using the following formula to take into account the natural mortality:

$$
100\left(1.0-\frac{\text { survival treated }}{\text { survival control }}\right)=\text { corrected } \% \text { control }
$$

All four insecticides were extremely successful in killing pine butterfly larvae at the dosages tested. As can be seen from Table 2, there was little difference between the high and low dosages for each material. 

Table 2. Survival ratios of pine butterfly larvae treated by ground sprays of four insecticides.

\begin{tabular}{|c|c|c|c|c|c|}
\hline Treatment & $\begin{array}{l}\text { Cluster } \\
\text { number }\end{array}$ & $\begin{array}{l}\text { Pre-spray } \\
\text { densityl }\end{array}$ & $\begin{array}{l}\text { Post-spray } \\
\text { density }\end{array}$ & $\begin{array}{l}\text { Survival } \\
\text { ratio }\end{array}$ & $\begin{array}{l}\text { Corrected } \\
\% \text { Control }\end{array}$ \\
\hline $\begin{array}{l}\text { Stabilized Pyrethrins } \\
.02 \mathrm{lb} / 10 \mathrm{gal} \text {. }\end{array}$ & $\begin{array}{r}6 \\
19 \\
25 \\
\end{array}$ & $\begin{array}{l}.1285 \\
.1807 \\
.2090 \\
1727\end{array}$ & $\begin{array}{l}.0042 \\
.0000 \\
.0000 \\
\end{array}$ & $\begin{array}{l}.0328 \\
.0000 \\
.0000 \\
\end{array}$ & \\
\hline Average & & .1121 & .0014 & .0081 & 98.78 \\
\hline $\begin{array}{l}\text { Stabilized Pyrethrins } \\
01 \mathrm{lb} / 10 \text { gal. }\end{array}$ & $\begin{array}{r}2 \\
16 \\
23 \\
\end{array}$ & $\begin{array}{l}.5475 \\
.4388 \\
.3013 \\
\end{array}$ & $\begin{array}{l}.0038 \\
.0074 \\
.0013 \\
\end{array}$ & $\begin{array}{l}.0069 \\
.0169 \\
.0042 \\
\end{array}$ & \\
\hline Average & & .4292 & .0042 & .0098 & 98.53 \\
\hline $\begin{array}{l}\text { Resmethrin } \\
.021 \mathrm{~b} / 10 \mathrm{gal} \text {. }\end{array}$ & $\begin{array}{l}10 \\
11 \\
22 \\
\end{array}$ & $\begin{array}{l}.8620 \\
.6535 \\
.2307 \\
\end{array}$ & $\begin{array}{l}.0000 \\
.0000 \\
.0000 \\
\end{array}$ & $\begin{array}{l}.0000 \\
.0000 \\
.0000 \\
\end{array}$ & \\
\hline Average & & .5810 & .0000 & .0000 & 100.00 \\
\hline $\begin{array}{l}\text { Resmethrin } \\
.011 \mathrm{~b} / 10 \mathrm{gal} \text {. }\end{array}$ & $\begin{array}{l}20 \\
21 \\
24 \\
\end{array}$ & $\begin{array}{r}.5425 \\
.7308 \\
.3532 \\
\end{array}$ & $\begin{array}{l}.0000 \\
.0000 \\
.0013 \\
\end{array}$ & $\begin{array}{l}.0000 \\
.0000 \\
.0037 \\
\end{array}$ & \\
\hline Average & & .5401 & .0004 & .0007 & 99.89 \\
\hline $\begin{array}{l}\text { Zectran } \\
.075 \mathrm{lb} / 10 \mathrm{ga} 7 .\end{array}$ & $\begin{array}{l}12 \\
18 \\
26 \\
\end{array}$ & $\begin{array}{l}.6570 \\
.4045 \\
.1114 \\
\end{array}$ & $\begin{array}{l}.0000 \\
.0000 \\
.0000 \\
\end{array}$ & $\begin{array}{l}.0000 \\
.0000 \\
.0000 \\
\end{array}$ & \\
\hline Average & & .3925 & .0000 & .0000 & 100.00 \\
\hline $\begin{array}{l}\text { Zectran } \\
.051 \mathrm{~b} / 10 \mathrm{ga} .\end{array}$ & $\begin{array}{r}1 \\
14 \\
27 \\
\end{array}$ & $\begin{array}{l}.3178 \\
.2907 \\
.2044 \\
\end{array}$ & $\begin{array}{l}.0000 \\
.0000 \\
.0000 \\
\end{array}$ & $\begin{array}{l}.0000 \\
.0000 \\
.0000 \\
\end{array}$ & \\
\hline Average & & .2713 & .0000 & .0000 & 100.00 \\
\hline $\begin{array}{l}\text { Malathion } \\
.83 \mathrm{lb} / 10 \mathrm{gal} \text {. }\end{array}$ & $\begin{array}{r}3 \\
7 \\
13 \\
\end{array}$ & $\begin{array}{l}.2162 \\
.3063 \\
.3773 \\
\end{array}$ & $\begin{array}{l}.0000 \\
.0000 \\
.0000 \\
\end{array}$ & $\begin{array}{l}.0000 \\
.0000 \\
.0000 \\
\end{array}$ & \\
\hline Average & & .2995 & .0000 & .0000 & 100.00 \\
\hline
\end{tabular}



Table 2. Continued

\begin{tabular}{|c|c|c|c|c|c|}
\hline Treatment & $\begin{array}{l}\text { Cluster } \\
\text { number }\end{array}$ & $\begin{array}{l}\text { Pre-spray } \\
\text { density }\end{array}$ & $\begin{array}{l}\text { Post-spray } \\
\text { density? }\end{array}$ & $\begin{array}{c}\text { Survival } \\
\text { ratio }\end{array}$ & $\begin{array}{l}\text { Corrected } \\
\% \text { Controt }^{2}\end{array}$ \\
\hline $\begin{array}{l}\text { Malathion } \\
.21 \mathrm{~b} / 10 \mathrm{gal} \text {. }\end{array}$ & $\begin{array}{r}4 \\
8 \\
17 \\
\end{array}$ & $\begin{array}{r}.3535 \\
.3605 \\
.3455 \\
\end{array}$ & $\begin{array}{l}.0000 \\
.0000 \\
.0000 \\
\end{array}$ & $\begin{array}{l}.0000 \\
.0000 \\
.0000 \\
\end{array}$ & \\
\hline Average & & .3531 & .0000 & .0000 & 100.00 \\
\hline Check & $\begin{array}{r}5 \\
9 \\
15 \\
\end{array}$ & $\begin{array}{l}.2903 \\
.4646 \\
.3355 \\
\end{array}$ & $\begin{array}{r}.0787 \\
.4136 \\
.2398 \\
\end{array}$ & $\begin{array}{l}.2711 \\
.8902 \\
.7148 \\
\end{array}$ & \\
\hline Average & & .3629 & .2432 & .6702 & \\
\hline
\end{tabular}

1 Larvae per Tinear inch of foliage.

$2100(1.0$ - survival treated $\dot{-}$ survival control $)=$ corrected percent control. 



\section{DISCUSSION}

The complete or near-complete control of pine butterfly larvae on the sample trees by application of all four materials was achieved with possible help from the following factors:

1. Small larvae size - Larvae on the sample trees were predominantly 1st and 2nd instar stages and, because of their small size, were very susceptible.

2. Larval feeding habits - Pine butterfly larvae are not protected by foliage growth, webbing, etc., as are some other defoliators, such as spruce budworm. Their habit of feeding and resting in exposed groups near the needle tips when small (Figure 7) makes them vuinerable to application of non-persistent sprays such as the four tested.

3. Amount of spray applied - A7l materials were applied to test trees to the point of run-off, making sure all foliage was wet. Open-grown ponderosa pines from 30 to 40 feet high were given an average of 10 gallons of spray.

Although the test sprays were applied with equipment that developed up to 200 psi pressure and was capable of reaching to heights of 50 feet and more, any of a variety of conventional sprayers available to private landowners would be sufficient to apply the material. The important consideration with non-persistent sprays would be to make certain the entire complement of foliage was covered.

Test results indicated that any of the four materials would be suitable for control of pine butterfly on yard, shade and other high-value trees by private home owners and land managers. Results showed that excellent control can be obtained with the low dosage rates (.01 1b/10 gallons for Resmethrin and stabilized pyrethrins, .21 lb/10 gallons for malathion and .05 1b/10 gallons for Zectran). 



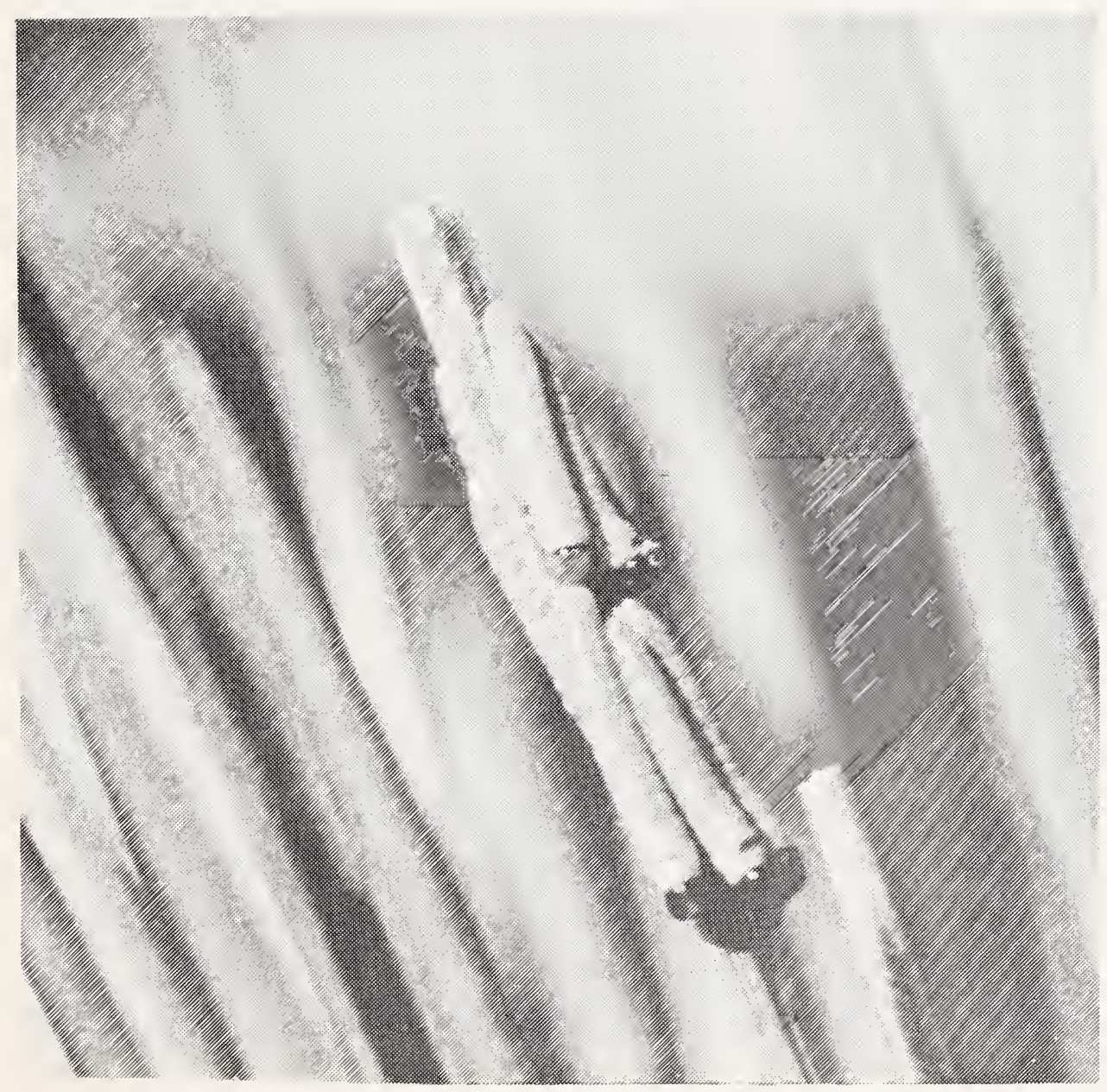

Figure 7. Exposed feeding and resting habit of pine butterfly larvae. 



\section{COOPERATORS}

This pine butterfly ground spray test was a cooperative project involving the following agencies:

Montana Department of Natural Resources and Conservation

Division of Forestry

Missoula, Montana

U.S. Forest Service, Region 1

Division of State and Private Forestry

Missoula, Montana

Insecticide Evaluation Project

PSW Forest and Range Experiment Station

Berkeley, California

Test materials were contributed by the following companies:

Dow Chemical Co.

McLaughlin Gormley King Co.

S.B. Penick and Co. 



\section{LITERATURE CITED}

Bousfield, W. E., and W. M. Ciesla. 1971. Evaluation of a pine butterfly infestation in the Bitterroot Valley, Montana, 1971. USDA Forest

Service, N. Reg., Insect and Disease Rept. No. 71-32, 5 p.

Bousfield, W. E., and J. E. Dewey. 1972. An evaluation of the pine butterfly outbreak in the Bitterroot and Missoula area. USDA Forest Service, N. Reg., Insect Disease Rept. No. I-72-12, 9 p.

Cole, Walter E. 1966. Effect of pine butterfly defoliation on ponderosa pine in southern Idaho. USDA Forest Service, Research Note INT-46, 7 p.

Cole, Walter E. 1971 (revised). Pine butterfly. USDA Forest Service, Forest Pest Leaflet 66, 3 p.

Dewey, J.E., H. E. Meyer, R. C. Lood, and S. Kohler. 1973. A pine butterfly impact survey on the Bitterroot National Forest and State of Montana lands - 1972. USDA Forest Service, N. Reg., Insect Disease Rept. No. 73-12, 10 p.

Evenden, James C. 1940. Effects of defoliation by the pine butterfly upon ponderosa pine. Jour. of Forestry 38: 949-955.

Lyon, Robert L., and Sylvia J. Brown. 1971. Contact toxicity of 14 insecticides tested on pine butterfly larvae. USDA Forest Service, Research Note PSW-257, 4 p. 


